Allen et al, eds. Mechanisms of mucosal protection in the upper gastrointestinal tract. New York: Raven Press, 1984: 119-23.

6 Konturek SJ, Bilski J, Kwiecien N, Obtuløwicz W, Kopp B, Oleksy J. De-Nol stimulates gastric and duodenal alkaline secretion through prostaglandin dependent mechanism. Gut 1987; 28: 1557-63.

7 Rees WDW, Garner A, Heylings JR, Flemstrom $G$. Effect of carbenoxolone on alkaline secretion by isolated amphibian gastric and duodenal mucosa. Eur f Clin Invest 1981; 11: 481-6.

\section{Systemic factors and luminal contents in gut adaptation}

SIR, - I read with interest the elegant paper by Albert et al (Gut 1990; 31: 311-6). They state that the atrophic effect of diversion of luminal contents can be counteracted by systemic growth factors released as part of the adaptive response and, accordingly, systemic growth factors are not dependent on a permissive effect of luminal contents.

We used a different strategy to address a similar question.' The behaviour of jejunal to colonic mucosal autografts was studied in an experimental animal model of short bowel syndrome (SBS). Histological appearances, enterocyte enzyme activities, and in vitro glucose transport were studied at the donor and recipient graft sites in control, SBS, and gastrocolic fistula 5 week old $150 \mathrm{~g}$ SpragueDawley rats. Small intestinal function was maintained in the jejunocolonic graft after $80 \%$ small bowel resection; animals in which small bowel was not resected showed loss of graft function and enzyme activity. Total parenteral nutrition did not alter graft behaviour but improved the postoperative mortality of the procedures. In addition, after creation of a gastrocolic fistula, the jejunum to colon graft lost functional jejunal activities. This may be interpreted in one of two ways. Either jejunal chyme and pancreaticobiliary secretion is a prerequisite for adaptation, as has been widely proposed previously, ${ }^{23}$ or the same explanation may be given as proposed by Albert $e t a l$ in their paper. This dual intepretation also applies to their study: it may, therefore, be premature to discount the importance of luminal nutrition.

A K BANERJEE

Departments of Surgery and Clinical Biochemistry, King's College Hospital,
London SE5 $9 P \mathcal{P F}$

1 Banerjee AK, Chadwick SJD, Peters TJ. Adaptation of jejunal to colonic mucosal autografts in experimentally induced short bowel syndrome. Dig Dis Sci 1990; 35: 340-8.

2 Williamson RCN. Intestinal adaptation I. Structural, functional and cytokinetic changes. $N E n g$ f Med 1978; 298: 1393-402.

3 Dowling RH, Booth CC. Structural and functional changes following small intestinal resection in the rat. Clin Sci 1967; 32: 139-49.

\section{Reply}

SIR, - The results of our study indicated, as stated by the correspondents, that the action of systemic growth factors released in response to the short bowel syndrome, are not dependent on the presence of luminal contents: they induce proliferation in bypassed loops where neither nutrients nor pancreaticobiliary secretions are present. This conclusion should not be misinterpreted to mean that we consider that luminal nutrients or pancreaticobiliary secretions, or both, are unimportant in other situations. We agree that the importance of luminal contents in the adaptive process should not be discounted. However, such factors could not have been responsible for the prolif- erative response seen in the bypassed loop in the rats subjected to $85 \%$ jejunoileal bypass. Previous studies have indicated the presence of circulating growth factors in the short bowel syndrome, but it has remained possible that these are simply due to an epiphenomenon related to leakage of locally acting growth factors into the circulation. Our findings suggest that they play an important, and not a minor secondary, part.

GRAEME P YOUNG
VIOLET ALBERT
Department of Medicine,
Royal Melbourne Hospital,

tbourne Hospital,

Why do patients with ulcerative colitis relapse?

SIR, - When dedicated research workers spend much effort employing methodology bound to fail in its objective it is always regrettable. In this instance I refer to reliance on self reported answers by ulcerative colitis sufferers to questionnaires about their emotional feelings and allegedly stressful life events reported in the article by Riley et al (Gut 1990; 31: 179-83).

Given the degree of unanimity of view expressed by critics of the above methods, ${ }^{1-5}$ and of the comparable futility of dependence on only one or two interviews to uncover emotional factors ${ }^{6-12}$ in inflammatory bowe disease, it is surprising that the authors of the article did not discuss these criticisms, or even refer to them.

It is now 40 years since I commented on these emotional aspects in a large series ${ }^{13}$. "Colitis patients may be ready talkers about their symptoms but they are "dumb" about their emotional feelings.' Suggestions were then offered on how they could be helped to do so. McMahon et al,' in criticising the insensitivity of studies by Feldman et $a l^{14}$ and Mendeloff $e t a l,{ }^{15}$ wrote that 'they view psychopathology largely in symptomatic terms, and rely heavily on patients' self-reports,' and added that 'patients with inflammatory bowel disease are notoriously poor reporters of their inner psychic life.' They also cited Schmitt, who wrote that it is not surprising that ulcerative colitis patients [referring to Mendeloff's study] report fewer stressful life events in their lives' and 'the patients' extensive use of denial suggests that they are often unaware of the stress at a conscious level.' Ford and coworkers, ${ }^{7}$ writing of comparable experience of regional enteritis, said that 'it should not be surprising if patients with a degree of rigidity repression and guardedness noted in our study were to answer negatively to direct questions about emotional stress' and 'before these very guarded patients can allow themselves to talk freely a relationship must be established. Summarising the serious limitations of inventories and questionnaires in the investigation of all psychosomatic disorders, Pelser and $I^{3}$ have said: 'It is inevitable that questionnaires/ inventory techniques will always fail to uncover deeply repressed and unconscious feelings in patients whose very disability centres on their poverty of emotional expression.'

In an attempt to be constructive I would respectfully suggest that the answer to Riley $e$ al's question is open to any clinician who is prepared to acquire the sensitive interviewing techniques needed to uncover the typically provocative emotional stresses in these guarded patients, and to recognise that the process is likely to entail interviews over many weeks. ${ }^{136}$

5I W PAULlesea Road, 51 Anglesea Road,
Ipswich IP1 3Pf
I McMahon AW, Schmitt P, Paterson JF. Personality differences between inflammatory bowel ality differences between inflammatory bowel disease patients and their healthy
Psychosom Med 1973; 35: 91-103.

2 Schmitt BD. Personality and ulcerative colitis. $N$ Engl F Med 1970; 282: 689.

3 Paulley JW, Pelser HE (1989). Psychological management for psychosomatic disorders. Heidelberg: Springer Verlag, 1989: 38, 62: 324 5.

4 Karush A, Daniels GE, Flood C, O'Connor JF. Psychotherapy in chronic ulcerative colitis. Philadelphia: Saunders, 1977: 50-9.

5 Graham DT. What place in medicine for psychosomatic medicine? Psychosom Med 1979; 41 : 357-67

6 Grace WJ. Life stress and regional ileitis. Gastroenterology 1953; 23: 542-53.

7 Ford CV, Glober GA, Casteluovo-Tedesco P. A psychiatric study of patients with regional enteritis. $\mathcal{F A M A}$ 1969; 208: 311-5.

8 West R. Psychological factors in ulcerative colitis. Br Med F 1967; ii: 56

9 Engel GL. Psychological factors in ulcerative colitis. BrMed F 1967; ii: 56 .

10 Gainsborough H. Psychological factors in ulcerative colitis. $\mathrm{Br}$ Med $\mathcal{F}$ 1967; ii: 499.

11 Brown D. Emotion and ileitis. $\operatorname{Br} M e d F$ 1968; i: 179-80.

12 Paulley JW. Emotion and ileitis. Br Med F 1968; i: 180.

13 Paulley JW. Ulcerative colitis: a study of 173 cases. Gastroenterology 1959; 16: 566-76.

14 Feldman F, Cantor D, Soll S, Bachrach W Psychiatric study of a consecutive series of 34 patients with ulcerative colitis. $\mathrm{Br} \mathrm{Med} \mathcal{F} 1967$; iii: $14-7$.

15 Mendeloff AL, Monk M, Siegel CI, Lilienfeld, A. Illness experience and life stresses in patients with irritable colon and with ulcerative colitis. N Engl F Med 1970; 282: 14-7.

\section{Reply}

SIR, - Dr Paulley criticises our use of self rated questionnaires in patients with ulcerative colitis as he believes that colitis 'centres on a poverty of emotional expression.' Dr Paulley and others ${ }^{1-4}$ have for many years championed the psychosomatic model of ulcerative colitis. Their observations are extensive but, as all are uncontrolled, we would respectfully suggest that they are of limited value. Controlled studies have consistently failed to show an excess of psychiatric illness or stressful life events in patients with colitis. ${ }^{5-8}$

The rating scales we used have been well validated in both healthy subjects and patients with psychiatric illness. ${ }^{9-11}$ There is no objective evidence to suggest that patients with colitis have difficulty expressing their feelings through such scales.

In our experience most patients with ulcerative colitis will openly discuss psychological conflicts, and, despite our negative findings, many believe that stressful life events precipitate relapse. However, rumination, by both patient and doctor, is particularly common at times of disease relapse. Appropriately controlled studies are, therefore, essential if such biases are to be overcome.

In order to investigate events that may precipitate colitis relapse we studied a cohort of patients in established disease remission. Patients were assessed at 12 weekly intervals and were followed up to either relapse or completion at 48 weeks. The main advantage of such a study is that the patient serves as his or her own control. Using such a design we found that the frequency and severity of life events were equally matched in patients in relapse and remission and that those who relapsed graded life events no more stressful than those who stayed in remission. Anxiety and depression ratings were also similar in the two groups and did not correlate with disease activity.

We did not assess personality characteristics in our patients, although personality differences from controls are often cited to support the role of psychological factors in the patho- 
genesis of ulcerative colitis. ${ }^{12-13}$ It should not need stating that ulcerative colitis is a chronic debilitating illness characterised by episodic bloody diarrhoea; many patients suffer faecal incontinence, some require surgical intervention, and some are at increased risk of colon cancer. That such patients have a tendency to neuroticism and introversion is, perhaps, not surprising.

We would not wish to discourage the detailed psychological assessment of patients with ulcerative colitis, but this will only improve our understanding of disease pathogenesis if undertaken in the setting of appropriately controlled clinical trials. Further uncontrolled observations would be at best unhelpful and at worst strengthen an already well established bias.

$S$ A RILEY

M J GOODMAN

Hope Hospital, Leigh Infirmary, and Bury General Hospital, Manchester

1 Paulley JW. Ulcerative colitis: a study of 173 cases. Gastroenterology 1959; 16: 566-76.

2 Paulley JW, Pelser HE. Psychological managemen for psychosomatic disorders. Heidelberg: Springe Verlag, 1989: 70-81.

3 Groen J. Psychogenesis and psychotherapy of ulcerative colitis. Psychosom Med 1947; 9: 151 74.

4 Engel GL. Studies of ulcerative colitis. III. The nature of the psychologic process. Am $\mathcal{F} \mathrm{Med}$ 1955; 19: 231-56.

5 Feldman F, Cantor D, Soll S, Bachrach W. Psychiatric study of a consecutive series of 34 patients with ulcerative colitis. Br Med F 1967 iii: $14-17$.

6 Mendeloff AL, Monk M, Siegel CI, Lilienfeld A Illness experience and life stresses in patients with irritable colon and with ulcerative colitis. $N$ Engl F Med 1970; 282: 14-7.

7 Elser MD, Goulston KJ Levels of anxiety in colonic disorders. $N$ Engl f Med 1973; 288: 1620

8 Helzer JE, Stillings WA, Chammas S, Norland CC, Alpers DH. A controlled study of the association between ulcerative colitis and psychiatric diagnosis. Dig Dis Sci 1982; 27: 513-8.

9 Paykel ES, Prussoff BA, Uhlenhuth EH. Scaling of life events. Arch Gen Psychiatry 1971; 25 340-7

10 Kearns NP, Cruikshank CA, McGuigan KJ, Riley SA, Shaw SP, Snaith RP. A comparison of depression rating scales. Br $\mathcal{F}$ Psychiatry 1982 141: 45-9.

11 Zigmond AS; Snaith RP. The hospital anxiety and depression scale. Acta Psychiatr Scand 1983; 67: 361-70.

12 McMahon AW, Schmitt P, Paterson SF, Roth man E. Personality differences between inflammatory bowel disease patients and their healthy matory bowel disease patients and their healt

13 Robertson DAF, Ray J, Diamond I, Edwards JG. Personality profile and effective state of patient with inflammatory bowel disease. Gut 1989; 30: 623-6.

\section{Enteropathy associated with HIV}

SIR, - We read with interest the study by Cummins et al (Gut 1990; 31: 317-21) on the enteropathy associated with HIV infection. There is a growing body of evidence for small bowel pathology in patients infected with the human immunodeficiency virus (HIV), and there is broad agreement that atrophy of villi is characteristic of such enteropathy.' ${ }^{\prime}$ Furthermore, there is evidence that jejunal mucosa pathology has functional importance in that reduced fat absorption correlates with the degree of villous atrophy. ${ }^{2}$

There are, however, conflicting reports on the changes in crypt cell proliferation in association with such villous atrophy. The paper by Cummins et al reports jejunal crypts of normal length, but with increased mitotic rate, in HIV infected patients. This is in general agreement with our own findings. ${ }^{1}$ As Cummins et al reiterate, we found a broad spread in crypt length in our patients, ranging from hypoplastic (in one patient with AIDS) through normality to hyperplastic. However the mean jejunal crypt length in our total of 20 HIV infected patients suggested hyperplasia. Notably, we found a strong correlation be tween the degree of atrophy of villi and the degree of hyperplasia of crypts, and faced with these data it is difficult to avoid the conclusion that there may be a causal (rather than coincidental) relation between these two variables.

It is well recognised that enteric infection may induce hyperplastic villous atrophy, and no doubt the dynamics of HIV enteropathy are complicated by opportunistic infections (even, possibly, with as yet unrecognised pathogens). Ullrich $e a^{4}$ have attempted to unravel the two and have described an HIV specific hypoplastic enteropathy, masked in some patients by the crypt hyperplasia induced by secondary pathogens. We quantified hyperplastic HIV enteropathy also in the absence of indentifiable opportunistic infections, but the paper by Cummins et al fails to exclude the effects of other pathogens.

Clearly, the mechanisms underlying the villous atrophy of HIV enteropathy remain elusive and are likely to be multifactorial. Its clarification may have to await an in vitro or animal model of HIV infection, when complicating factors can be carefully controlled.

P A BATMAN

Department of Histopathology, Bradford Royal Infirmary M S KAPEMBWA G E GRIFFIN

Department of Communicable Diseases, St George's Hospital Medical School, London

1 Batman PA, Miller ARO, Forster SM, Harris JRW, Pinching AJ, Griffin GE. Jejunal enteropathy associated with human immunodeficiency pathy associated with human immunodeficiency virus infection: quantitat

2 Miller ARO, Griffin GE, Batman P, et al. Jejuna mucosal architecture and fat absorption in male homosexuals infected with human immunodeficiency virus. $Q \mathcal{F}$ Med 1988; 69: 1009-19.

3 Cunningham A, Grohman G, Harkness J, et al. Gastrointestinal viral infections in homosexual men who were symptomatic and sero-positive fo human immunodeficiency virus. F Infect Dis 1988; 158: 386-91.

4 Ullrich R, Zeitz M, Heise W, L'Age M, Hoffken G, Riecken EO. Small intestinal structure and function in patients infected with human immunodeficiency virus (HIV): evidence for HIV nodeficiency virus (HIV): evidence for HIV-
induced enteropathy. Ann Intern Med 1989; 111: induced.

\section{Reply}

SIR, - We thank Batman and colleagues, for commenting on our paper. Both ourselves ${ }^{1}$ and Ullrich $e t a l^{2}$ have described villous atrophy and impaired crypt hyperplasia of the small intestine in HIV infection, particularly in patients with AIDS related complex or AIDS. Ullrich $e$ al further found crypt hypoplasia in AIDS subjects who did not have enteric infections. Batman $e t a l^{3}$ have argued that the enteropathy of HIV infection has crypt hyperplasia, as they found a correlation of crypt length and villous atrophy, although they could show no difference in crypt length. We nevertheless argue that the enteropathy associated with HIV infection is a different pattern to that seen in other enteropathies, as perhaps best exemplified by coeliac disease in which crypt hyperplasia is clearly discernible both by increased crypt length and increased mitotic count per crypt. One explanation for these data could be that some crypt hyperplasia occurs in HIV infection that has not yet progressed to AIDS related complex or AIDS, especially in response to enteric infections. As CD4 lymphocyte depletion occurs systemically and mucosally, the immune 'drive' for crypt proliferation is increasingly impaired. Longitudinal studies will help to confirm such an interpretation.

$$
\begin{array}{r}
\text { A G CUMMINS } \\
\text { J T LaBROOY } \\
\text { D J C SHEARMAN } \\
\text { Queen Elizabeth Hospital, } \\
\text { Woodville South, } \\
\text { South Australia 501I }
\end{array}
$$

Cummins AG, LaBrooy JT, Stanley DP, Rowland $\mathrm{R}$, Shearman DJC. Quantitative histological
study of enteropathy associated with HIV infection. Gut 1990; 31: 317-21.

2 Ullrich R, Zeitz M, Heise W, L'Age M, Höffken $G$, Riecken EO. Small intestinal structure and function in patients infected with human immunodeficiency virus (HIV): evidence for HIV induced enteropathy. Ann Intern Med 1989; 111 15-21

3 Batman PA, Miller ARO, Forster SM, Harris JRW, Pinching AJ, Griffin GE. Jejunal enteropathy associated with human immunodeficiency virus infection: quantitative histology. $\mathcal{f}$ Clin Pathol 1989; 42: 275-81.

\section{NOTES}

\section{Falk Symposia, 1990}

These will take place in Freiburg, West Germany as follows:

8-10 Oct Hepatic metabolism

11-13 Oct Bile acids as therapeutic agents

15-17 Oct Mechanisms of peptic ulcer healing

18-20 Oct Inflammatory bowel diseases

Further information: Falk Foundation eV, Leinenweberstrasse 5, Postfach 6529, D-7800 Freiburg, West Germany.

\section{Endoscopy workshop}

The Chinese Society of Digestive Endoscopy, C.M.A. and the Hong Kong Society of Digestive Endoscopy will be holding the International Workshop and Symposium on Therapeutic Endoscopy and Gastroenterology on 9-12 October 1990 in Beijing, China.

Further details: Dr Joseph Leung, Department of Medicine, Prince of Wales Hospital, Shatin NT, Hong Kong. Tel: (852)6363128/5; Fax: (852)-6350075.

\section{Sir Francis Avery Jones BSG Research Award 1991}

Applications are invited by the Education Committee of the British Society of Gastroenterology who will recommend to Council the recipient of the 1991 Award. Applications (15 copies) should include:

(1) a manuscript (2 A4 pages only) describing the work conducted;

(2) a bibliography of relevant personal publications;

(3) an outline of the proposed content of the lecture, including title;

(4) a written statement confirming that all or a substantial part of the work has been personally conducted in the United Kingdom or Eire.

The Award consists of a medal and a $£ 100$ prize. Entrants must be 40 years or less on 31 December 1991 but need not be a member of the BSG. The recipient will be required to deliver a 40 minute lecture at the Spring Meeting of the Society in Manchester in 1991. Applications (15 copies) should be made to: The Honorary Secretary, BSG, 3 St Andrew's Place, Regent's Park, London NW1 4LB by 1 December 1990. 